\title{
RECONCEPTUALISING SHAREHOLDER REMEDIES TO MITIGATE THE PROBLEMS CAUSED BY THE OVERLAP BETWEEN SECTION 994 AND PART 11 COMPANIES ACT 2006
}

\begin{abstract}
Shenara Perera*
Abstract: The contemporary paradigm relating to shareholder remedies under English company law identifies a fundamental overlap between the Section 994 and Part 11 of the Companies Act 2006. The underlying cause of the overlap is that an alleged breach of directors' duties can establish a claim under both remedial jurisdictions. This article argues the overlap between the jurisdictions generates three undesirable consequences. First, shareholders have used s.994 to obtain personal relief on a corporate claim, as opposed to pursuing a derivative claim for corporate relief. Second, s.994 has been used to obtain corporate relief on a corporate claim, instead of bringing a derivative claim. Third, shareholders can exploit s.994 to obtain an order authorising a derivative claim, effectively circumventing the threshold test in $\mathrm{Pt} 11$. The article explores the undesirable impact of these consequences for English company law. In each case, the article recommends three reform proposals which, if implemented, would reconceptualise shareholder remedies under English company law and mitigate the problems caused by the overlap between s.994 and Pt 11 .
\end{abstract}

\section{A. INTRODUCTION}

Fundamental to the concept of shareholder remedies under English company law is the phenomenon that 'directors owe their fiduciary duties to the company; not to the shareholders'. ${ }^{1}$ The phenomenon leads to the inference that breaches of directors' duties are wrongs committed against the company, in respect of which the company may commence a claim against the directors for corporate redress, by applying the proper plaintiff rule in Foss $v$ Harbottle. ${ }^{2}$ Alternatively, a shareholder can commence a derivative claim to obtain redress for the company under Part 11 of the Companies Act 2006 (CA 2006). ${ }^{3}$ In respect of personal wrongs, a shareholder can rely on the unfair prejudice remedy under Section 994(1) CA 2006, ${ }^{4}$ to obtain personal, but not corporate, relief. ${ }^{5}$ In the event a petitioner seeks personal relief for a corporate loss, the court must, ideally, strike out the claim as contrary to the 'no reflective loss' rule. ${ }^{6}$

\footnotetext{
*Shenara Sewwandhee Perera, LLM Corporate Law (Distinction), University College London; LLB (Hons), University of Southampton. The author may be contacted at: t.perera.17@ucl.ac.uk. I am thankful to Professor Brenda Hannigan for her guidance, Professor Carsten Gerner-Buerle and Professor Paul Davies for marked feedback, Rabiya Khawaja, Andrew McLean and Joyman Lee for editorial support.

${ }^{1}$ Companies Act 2006, s 170(1) (CA 2006); Percival v Wright [1902] 2 Ch 421.

2 (1843) 67 ER 189, (1843) 2 Hare 461. Refer section B(1) for a brief account of the rule.

${ }^{3}$ Refer section $\mathrm{B}(2)$ for a brief account of the remedy.

${ }^{4}$ Refer section B(3) for a brief account of the remedy.

5 Jennifer Payne, 'Shareholders' Remedies Reassessed' (2004) 67(3) Modern Law Review 500.

${ }^{6}$ Prudential Assurance Co Ltd v Newman Industries Ltd (No.2) [1982] Ch 204, [1982] 1 All ER 366367. Refer section $\mathrm{B}(4)$ for a brief account of the rule.
} 
The conventional paradigm that corporate claims are inherently within the ambit of the derivative jurisdiction and that s.994 is a personal remedy for shareholders' personal claims, has been a subject of significant ambiguity. ${ }^{7}$ The contemporary paradigm relating to shareholder remedies identifies a fundamental 'overlap' between the s.994 and derivative claims jurisdictions. The underlying cause of the overlap is that 'an alleged breach of directors' duties can establish a claim under both remedial jurisdictions'. ${ }^{8}$ Therefore, the present article focuses on the debate on 'directors as wrongdoers', as opposed to third parties such as solicitors. Although a breach of directors' duties owed to the company is primarily a wrong done to the company, shareholders can assert that such a breach is 'conduct which is unfairly prejudicial to the interests of the members generally'. ${ }^{9}$ There is an extensive list of cases exhibiting courts' acceptance that breaches of directors' duties can establish a claim under s.994. ${ }^{10}$ Therefore, the article does not expand on the cause of the overlap. ${ }^{11}$

Rather, there are two primary objectives of the article. Firstly, I seek to signify that the overlap between the two remedial jurisdictions generates the following three undesirable consequences. A) Shareholders have used s.994 to obtain personal relief on a corporate claim, as opposed to pursuing a derivative claim for corporate relief. ${ }^{12} \mathrm{~B}$ ) S.994 has been employed to obtain corporate relief on a corporate claim, instead of bringing a derivative claim. ${ }^{13}$ C) Shareholders can exploit s.994 to obtain an order authorising a derivative claim, effectively circumventing the threshold test in Pt $11 \mathrm{CA}$ 2006. ${ }^{14}$ Secondly, in each case, I recommend three reform proposals that aim to mitigate the problems caused by the overlap between s.994 and Pt 11 CA 2006. Subsection 1 presents a summary of the three undesirable consequences and the reform proposals.

\footnotetext{
${ }^{7}$ Andy Gray, 'The Statutory Derivative Claim: An outmoded superfluousness?' (2012) Company Lawyer 33(10) 296.

${ }^{8}$ Charnley Davies Ltd (No. 2), Re [1990] BCC 625.

${ }^{9}$ Lowe v Fahey [1996] 1 BCLC 262; Little Olympian Each-Ways Ltd (No.3), Re [1995] 1 BCLC 636; Allmark v Burnham [2005] 2 BCLC 437; Brenfield Squash Racquets Club Ltd, Re [1996] 2 BCLC 184; Lloyd v Casey [2002] 1 BCLC 454; Dalby v Bodilly [2005] BCC 627.

${ }^{10}$ Re Cumuana Ltd [1986] BCLC 430; Grace Biagioli [2006] BCLC 70; Re McCarthy Surfacing Ltd [2009] 1 BCLC 622; Tobian Properties Ltd, Re Attwood v Maidment [2012] EWCA Civ 998, [2013] 2 BCLC 567.

${ }^{11}$ That is, the same facts can give rise to two legal dimensions.

${ }^{12}$ Atlasview Ltd v Brightview Ltd [2004] EWHC 1056 (Ch), [2004] BCC 542.

${ }^{13}$ Clark v Cutland [2003] EWCA Civ 810, [2003] 2 BCLC 393; Anderson v Hogg [2002] BCC 923; Bhullar v Bhullar [2003] EWCA Civ 424, 2 BCLC 241; Gamlestaden Fastigheter AB v Baltic Partners Ltd [2008] 1 BCLC 468 PC (Jersey).

${ }^{14}$ CA 2006, s.996(2)(c).
} 


\section{Reconceptualising Shareholder Remedies to Mitigate the Problems Caused by the Overlap Between Section 994 and Part 11 Companies Act 2006}

The remainder of the article is presented in four parts. Section B provides a summary of the core concepts and laws that underpin the research topic. Section $\mathrm{C}$ conducts a detailed case analysis to critically evaluate the impacts of utilising s.994 to obtain personal relief on a corporate claim and concludes by forwarding a mitigating solution to the issue. Section D deals with the concerns raised when utilising s.994 to obtain corporate relief on a corporate claim and concludes by recommending a workable legal framework to apply in those circumstances. Section E aims to signify the difficulties that arise as a result of utilising s.994 to authorise a derivative claim and concludes by providing a middle-ground solution to mitigate the adverse impacts.

\section{The Three Undesirable Consequences: A Summary}

The first undesirable consequence generated by the overlap is the use of s.994 to seek personal relief on a corporate claim. This leads to the following predicaments. Firstly, where the court discards the 'no reflective loss' rule and orders personal relief to redress a corporate wrong, the shareholder obtains double recovery against the wrongdoing director. ${ }^{15}$ Secondly, ordering a personal remedy against the director in breach may consequently reduce the value of the company's claim against the director. ${ }^{16}$ Thirdly, the proper plaintiff rule in Foss is discarded where the court allows the shareholder to petition for a corporate wrong. As a result, the 'separate legal entity' status of the company is undermined because the remedy for the corporate loss is directed towards a shareholder and not towards the company. ${ }^{17}$ Fourthly, where the shareholder opts for a personal remedy, and there is no claim commenced by or on behalf of the company, the law fails to cure the loss endured by the company.

Consequently, to fully recover the loss sustained by the company, each shareholder would have to bring similar personal claims for the same corporate wrong, leading to an inefficient multiplicity of litigation, being costlier than if the court required a derivative action to be commenced. ${ }^{18}$ Moreover, where shareholders lack the resources to bring personal claims, justice for the corporate wrong will be denied altogether. Lastly, and most importantly, the article argues that in circumstances where the company is in the vicinity of insolvency, ordering personal relief for a corporate

\footnotetext{
15 Jennifer Payne, 'Sections 459-461 Companies Act 1985 in flux: the future of shareholder protection' (2005) 64(3) C.L.J. 647, 668.

${ }^{16}$ Han-Christoph Hirt, 'In What Circumstances Should Breaches of Directors' Duties Give Rise to a Remedy under ss.459-61 of the Companies Act 1985?' (2003) 24(4) The Company Lawyer 100, 109.

${ }^{17}$ CA 2006, s 16.

${ }^{18}$ Brenda Hannigan, 'Drawing boundaries between derivative claims and unfairly prejudicial petitions' (2009) 6 JBL 606, 616.
} 
wrong will directly and adversely affect the creditors' interests. ${ }^{19}$ To temper these adverse effects the article proposes an authoritative framework which uses the concept of 'reflective loss' as the underlying principle when dealing with petitions requesting personal relief on a corporate claim. In essence, the article submits that where the loss sustained is classified as a 'mere personal loss' the courts must require the petitioner to bring a derivative claim (as the 'personal loss' is 'reflective of the loss endured by the company' and redressing the company would redress the shareholder). If a shareholder seeks to secure a personal remedy based on a corporate claim, then he or she must successfully corroborate that the loss is 'separate and distinct' from the loss sustained by the company. ${ }^{20}$

The second undesirable consequence generated by the overlap - that is, the use of s.994 to seek corporate relief on a corporate claim - raises the following concerns. Firstly, it effectively undermines the sound policy underpinning the rule in Foss that 'companies are collective associations' and therefore the 'decision of whether or not to litigate in respect of wrongs done to the company should be left to the majority'. ${ }^{21}$ Secondly, the article argues that allowing shareholders to obtain corporate relief via a petition is a regressive step as it will risk rendering the derivative action obsolete. ${ }^{22}$ Moreover, the article submits that the courts, by ordering corporate relief under s.994 have opened the floodgates to increased litigation by shareholders and intensified the risk of abuse of process. With the aim of mitigating these adverse impacts, the article puts forward a workable legal framework to apply when the issue of ordering corporate relief on a petition comes before the court. The framework requires the court to ascertain whether the alleged breach of duty is a 'misconduct' or a 'mismanagement' ${ }^{23}$ The article submits that a petitioner can obtain corporate relief only in respect of mismanagement claims provided that the additional hurdle can be surpassed. The additional hurdle asserts that firstly, it must be possible to determine the value of the director's liability at the pleading stage. Secondly, the relief to be ordered must

\footnotetext{
19 ibid 618; McAskill v Fulton (2014) WL 8106597 [45] (Norris J).

${ }^{20}$ Payne, 'Sections 459-461 Companies Act 1985 Influx' (n 15) 674.

${ }^{21}$ Department of Trade and Industry, 'Modern Company Law for a Competitive Economy: Developing the Framework' (March 2000), [4.19], [4.67] (DTI: Developing the Framework).

${ }^{22}$ Brian Cheffins, 'Reforming the Derivative Action: The Canadian Experience and British Prospects' (1997) 1(2) CfiLR 259.

${ }^{23}$ Charnley (n 8) 783.
} 


\section{Reconceptualising Shareholder Remedies to Mitigate the Problems Caused by the Overlap Between Section 994 and Part 11 Companies Act 2006}

correspond with the redress that the company could have secured had it sued or if a derivative claim was established. ${ }^{24}$

The third undesirable consequence generated by the overlap is the use of s.994 to obtain an order authorising a derivative claim. This practice raises the fundamental issue of creating two different threshold tests to bring a derivative claim. ${ }^{25}$ Simply, the threshold test under Pt 11 CA 2006 contains two permission stages which principally examine whether it is 'in the interest of the company as a whole that the claim is pursued' ${ }^{26}$ In apparent contrast to the position under Pt 11 CA 2006, the grounds on which derivative actions may be granted on petitions do not expressly include considerations relating to the company's best interest. The Parliamentary intention behind placing the permission stages under Pt 11 CA 2006 was 'to avoid opening a "Pandora's Box" 27 to every disappointed shareholder' ${ }^{28}$ The critical argument is that using s.994 to authorise a derivative claim defeats this intention of the Parliament. The subsequent argument is that the authorisation of a derivative claim under s.994 discards the principle of majority in Foss because an individual shareholder decides whether or not to litigate, not the company. ${ }^{29}$ As a mitigating solution, the article puts forward a reform proposal which aims to retain the s.994 jurisdiction to authorise derivative claims, with the additional requirement that the section is utilised more in line with the Pt 11 CA 2006 requirements. ${ }^{30}$

\section{B. BACKGROUND INFORMATION AND DEFINITIONS}

The section provides the information relating to the core concepts and laws that underpin the research topic. Subsection 1 explains the rule in Foss. Subsections 2 and 3 present a brief account of the two remedial jurisdictions. Subsection 4 rationalises the 'no reflective loss' rule.

\section{The Rule in Foss}

The rule in Foss enunciates two cardinal principles of company law. First, the proper plaintiff rule which articulates that 'the proper plaintiff in respect of a wrong allegedly

\footnotetext{
${ }^{24}$ Chime Corp, $\operatorname{Re}$ [2004] 7 HKCFAR 546 [62].

${ }^{25}$ Ji Lian Yap, 'Authorising derivative actions on unfair prejudice petitions' (2011) 32(5) The Company Lawyer 150, 152.

${ }^{26}$ CA 2006, s 263(2)-(3).

${ }^{27}$ Julia Tang, 'Shareholder Remedies: Demise of the Derivative Claim?' (2012) 1(2) UCL Journal of Law and Jurisprudence 181.

${ }^{28}$ HL Deb 9 May 2006, vol 681, col 885 (Lord Sharman).

${ }^{29}$ Gray (n 7) 299.

${ }^{30}$ Yap (n 25).
} 
committed against the company, is prima facie the company' ${ }^{31}$ The proper plaintiff rule upholds the Salomon principle: that 'a company is an entity distinct from its members'. ${ }^{32}$ Second, the principle of majority rule means, 'where the professed wrong is a transaction which can be made binding on the company by a simple majority of the members, no member is entitled to initiate a claim in respect of it' ${ }^{33}$

\section{The Derivative Claims Jurisdiction}

The rule in Foss leads to the perception that corporate wrongs are inherently within the ambit of a derivative claim. ${ }^{34}$ To commence a derivative claim under the common law, a member had to surpass the 'fraud on the minority' and 'wrongdoer control' filters. ${ }^{35}$ With the Company Law Review adopting the recommendation by the Law Commission in 1997 to codify the common law derivative action, ${ }^{36}$ the derivative claim framework was placed within Pt 11 CA 2006. As per the statutory procedure, 'a shareholder can commence a derivative claim against any director in respect of negligence, default, breach of duty and breach of trust by a director of the company'. ${ }^{37}$ To 'continue the claim', Pt 11 CA 2006 asserts that 'a shareholder must obtain the court's permission in two stages'. ${ }^{38}$ At the first stage, the court must deny consent to continue the claim 'if the supporting evidence filed by the applicant fails to disclose a prima facie case' ${ }^{39}$ At the second stage, the court must consider a multiplicity of factors under ss. 263(2) and (3). Factors under s.263(2) are of a 'mandatory nature' thus obliging the court to dismiss the claim; factors under s.263(3) are 'discretionary'. In sum, the factors that the court must consider relate to the principal question 'whether it is in the interest of the company as a whole that the claim is pursued'.

\section{The Unfairly Prejudicial Remedy}

In the instance of the shareholder suffering a personal loss, redress to the shareholder is available via the unfair prejudice remedy under s.994(1) CA 2006. S.994 mirrors precisely the provisions formerly found in s.459 Companies 1985 Act as amended.

\footnotetext{
${ }^{31}$ Foss (n 2).

${ }^{32}$ Salomon v A Salomon \& Co Ltd [1897] AC 22, [1896] UKHL J1116-2.

${ }^{33}$ Foss (n 2); Edwards v Halliwell [1950] 2 All ER 1066 (Jenkins LJ); Prudential (n 6) 357.

${ }^{34}$ Gray (n 7).

${ }^{35}$ Prudential (n 6) [366]; Smith v Croft (No.2) [1987] 3 All ER 945.

36 DTI: Developing The Framework (n 20) [4.112]-[4.139]; DTI, 'Modern Company Law for a Competitive Economy: Final Report' (July 2001) [7.46]-[7.51] (DTI: Final Report); Law Commission, Shareholder Remedies (Law Com No 246, 1997) para 6.15; Poole and Roberts, 'Shareholder Remedies Corporate Wrongs and the Derivative Action' [1999] Journal of Business Law 99.

${ }^{37}$ CA 2006, s 260(3).

${ }^{38}$ CA 2006, s 261(1).

${ }^{39}$ CA 2006, s 261(2).
} 


\section{Reconceptualising Shareholder Remedies to Mitigate the Problems Caused by the Overlap Between Section 994 and Part 11 Companies Act 2006}

Under s.994 a shareholder can petition on the ground that 'the company's affairs are being or have been conducted in a manner that is unfairly prejudicial to the interests of members generally or of some part of its members (including at least himself), or that an actual or proposed act or omission of the company (including an act or omission on its behalf) is or would be so prejudicial'. As the House of Lords (HL) in O'Neill $v$ Phillips established, ${ }^{40}$ a claim of unfairness will only be successful 'where there has been some breach of the terms on which the member agreed that the affairs of the company should be conducted; or some use of the rules in a manner which equity would regard as contrary to good faith'. ${ }^{41}$ Upon successfully founding a s.994 petition, s.996(1) provides the court has 'a wide discretion' to make an order 'as it thinks fit' to provide redress.

\section{The 'No Reflective Loss' Rule}

Linked to the rule in Foss is the 'no reflective loss' rule originating in Day $v$ Cook, ${ }^{42}$ which was judicially approved by the Court of Appeal in Prudential Assurance Co Ltd $v$ Newman Industries Ltd (No.2), ${ }^{43}$ and considered in detail by the HL in Johnson $v$ Gore Wood. ${ }^{44}$ The 'no reflective loss' rule stipulates that 'a personal claim by a shareholder in respect of the diminution in value of his shareholding as a result of a wrong done to the company is misconceived and should be struck out, for the shareholder's loss is merely reflective of the loss suffered by the company, and if the company enforces its full rights against the wrongdoer the affected stakeholders can recover the loss'. ${ }^{45}$ As long as 'the company would ordinarily have a claim', the shareholder cannot recover a loss, even if 'the company declines or fails to sue', ${ }^{46}$ except 'where the wrongdoer disables the company from pursuing the claim'- in which case, the shareholder can bring a claim for what is a 'reflective loss' ${ }^{47}$ Although the

\footnotetext{
${ }^{40}$ [1999] 2 All ER 961, [1999] 2 BCLC 1.

41 ibid [8]; Prentice and Payne, 'Case Comment: Section 459 of the Companies Act 1984 - the House of Lords' view' (1999) 115 LQR 587; Robert Goddard, 'Case Comment: Taming the Unfair Prejudice Remedy: sections 459-461 of the Companies Act 1985 in the House of Lords' [1999] C.L.J. 487; A J Boyle, 'Case Comment: Unfair prejudice in the House of Lords' (2000) 21(8) The Company Lawyer 253.

42 [2001] EWCA Civ 592, [2002] 1 BCLC 1 [15f].

${ }^{43}$ Prudential (n 6).

${ }^{44}$ Johnson v Gore Wood [2002] 2 AC 1, [2001] 1 All ER 481.

45 Prudential (n 6) 366-67.

${ }^{46}$ Johnson (n 44) [337f]-[338b] (Lord Bingham); Jonathan Mukwiri, 'The No Reflective Loss Principle' (2005) 26(10) The Company Lawyer 304, 305.

${ }^{47}$ Giles v Rhind [2002] EWCA Civ 1428, [2003] 1 BCLC 1 [34]; Hans-Christoph Hirt, 'Companies in General' (2003) JBL 420.
} 
notion of 'reflective loss' can be critiqued, ${ }^{48}$ once it is accepted, it requires the court to refuse personal relief for corporate wrongs on the ground that 'the proper plaintiff for the loss suffered is the company itself' ${ }^{49}$

\section{S.994 PERSONAL RELIEF FOR A CORPORATE CLAIM}

The orthodox view holds that the rule in Foss and the 'no reflective loss' rule are the two main barriers to a corporate claim under s.994. ${ }^{50}$ Despite this ideal, 'an activist judiciary', ${ }^{51}$ and the 'elastic quality' of s.994, ${ }^{52}$ have led to litigants widely using s.994 where wrongs are done to the company to obtain personal relief for claims which involve reflective loss. ${ }^{53}$ This section deals with the subject matter in three parts. Subsection 1 evaluates the judgment in Atlasview Ltd v Brightview Ltd. ${ }^{54}$ Subsection 2 signifies the problematic consequences that follow when courts order personal relief for a corporate wrong under s.994. Subsection 3 proposes an authoritative framework in which, the concept of reflective loss plays a pivotal role in mitigating the problematic outcomes discussed in subsection 2.

\section{Personal Relief Under S.994 for Corporate Claims: A Case Analysis}

The wrongful conduct in Atlasview involved a breach of directors' duties. The petitioners mounted the argument that such a breach is 'conduct which is unfairly prejudicial to the interests of members generally' and requested various remedies including damages. ${ }^{55}$ The defendants requested the court to strike out the petition based on two credible counterarguments. Primarily, the alleged breach was 'not in respect of a duty owed to any shareholder', but a 'fiduciary duty owed to the company by directors' and therefore the proper plaintiff is prima facie the company. ${ }^{56}$ Consequently, 'any diminution in the value of the petitioners' shares' was 'merely reflective of the company's loss'. ${ }^{57}$ The court rejected the defendants' counterargument and accepted that a 'breach of director's duty is a typical case of conduct which is unfairly prejudicial

\footnotetext{
${ }^{48}$ Charles Mitchell, 'Shareholders' Claims for Reflective Loss' (2004) 120 L.Q.R. 457.

49 Payne, 'Sections 459-461 Companies Act 1985 Influx' (n 15) 670.

${ }^{50}$ Refer text to (n 31), (n 33) in section B(1) and text to (n 45), (n 46) and (n 47) in section B(4).

${ }^{51}$ D Sugarman, 'Reconceptualising Company Law: Reflections on the Law Commission's Consultation Paper on Shareholder Remedies' in Barry A.K. Rider (ed), The Corporate Dimension (Bristol: Jordans 1998), 208.

${ }^{52}$ Re Macro (Ipswich) Ltd [1994] 2 BCLC 404.

${ }^{53}$ Atlasview (n 12).

54 ibid.

55 ibid [18]-[21].

56 ibid [58].

57 ibid [58].
} 


\section{Reconceptualising Shareholder Remedies to Mitigate the Problems Caused by the Overlap Between Section 994 and Part 11 Companies Act 2006}

to the interests of members generally'. Thereby, the court took the view that refusing to apply s.994 in such a case would 'deprive the section of much of its value'. ${ }^{58}$

In the course of his judgment, Jonathan Crow relied on pre-Johnson ${ }^{59}$ cases such as Re A Company ${ }^{60}$ and Re Saul D Harrison, ${ }^{61}$ in which the courts ordered personal relief where a breach of directors' duties has occurred without raising the reflective loss point. ${ }^{62}$ Indeed, it is logical to assume that those cases were decided in the ways they were because the reflective loss argument was not well founded. ${ }^{63}$ Nevertheless, the article submits that it is questionable whether the fact that an argument was 'not raised in the past' is a valid basis for the court to declare that the argument cannot succeed in the present case.${ }^{64}$ More critically, the deputy judge's excessive reliance on pre-Johnson authorities instead of applying the precedent set in Johnson is disconcerting especially when the HL had thoroughly deliberated on the profile of reflective loss in that case. ${ }^{65}$ Furthermore, the deputy judge stated that Parliament changed the legislation 'in order to allow unfair prejudice to the interests of the members generally to be included'. Perhaps, allowing the reflective loss argument to succeed can supersede the open-ended effect of the amendment. ${ }^{66}$ However, stripping the effects of the amendment does not interrupt the provision of justice for breaches of directors' duties because there is a coexistence of causes of action for both the company (as the proper plaintiff) and shareholders (by way of a derivative claim) to redress such corporate wrongs. ${ }^{67}$

\section{Personal Relief Under S.994 for Corporate Wrongs: The Predicaments}

Atlasview sets the precedent that personal relief for corporate wrongs is acceptable. This section identifies the difficulties that follow from the precedent in five ways. Firstly, where the court discards the 'no reflective loss rule' and orders personal relief to redress a corporate wrong, the shareholder obtains double recovery against the wrongdoing director. Jonathan Crow, mirroring Lord Millet's view in Johnson, ${ }^{68}$ ascertains that where the shareholder seeks personal relief, the 'reflective loss' bar applies only when

\footnotetext{
58 ibid [61].

${ }^{59}$ Johnson (n 44).

${ }^{60}$ Company (No.005287 of 1985), Re [1986] 2 All ER 253 (1985) 1 BCC 99586 [284D-H] (Hoffmann $\mathrm{J})$.

${ }^{61}$ Re Saul D Harrison [1995] 1 BCLC 14 [18c-d] (Hoffmann J).

${ }^{62}$ Atlasview (n 12) [60].

63 ibid.

${ }^{64}$ Payne, 'Sections 459-461 Companies Act 1985 Influx' (n 15) 669.

65 ibid.

${ }^{66}$ Atlasview (n 12) [61].

${ }^{67}$ Day (n 42) [15]; Gardner v Parker [2004] EWCA Civ 781 [34].

${ }^{68}$ Johnson (n 44) [62].
} 
the issue of double recovery arises. ${ }^{69}$ The deputy judge claims that in order to avoid double recovery, the wrongdoer must compensate the company first and then purchase the shareholder's shares. ${ }^{70}$ Albeit the personal remedy sought under s.994 in Atlasview were damages, the most commonly requested remedy is a purchase order. ${ }^{71}$ Differing from the deputy judge's view, Payne states, 'in the instance where a breach causes loss to both the company and shareholder, double recovery against the director will be prevented only where redress is given to one victim at the expense of the other'. ${ }^{72}$ It is acknowledged that the advantage of making a purchase order in the context of a corporate wrong is that, the remedy in effect truncates two stages into one. ${ }^{73}$ Instead of obtaining corporate relief first and then selling the shares, the minority shareholder obtaining a purchase order can directly exit the company at the same value. ${ }^{74}$ However, agreeing with Payne, the article argues that, where the director compensates the company before purchasing the shareholder's shares, the shareholder obtains double recovery against the director as the valuation of shares at exit will include the compensation obtained by the company. Thus, the article submits that the courts must apply the 'no reflective loss' rule and deny personal relief for a corporate wrong in order to avoid the shareholder unjustly enriching himself by virtue of double recovery against the director.

Secondly, although a personal remedy does not adversely affect the company's assets (as the remedy is against the directors in breach, not against the company), it can affect the director's ability to meet subsequent claims, potentially reducing the value of the company's cause of action against the directors. ${ }^{75}$ Thirdly, when courts discard the 'no reflective loss' rule and allow shareholders to obtain personal relief on a corporate claim the proper plaintiff rule in Foss is discarded. Despite Jonathan Crow asserting that the "no reflective loss' rule applies only when the issue of double recovery arises, ${ }^{76}$ the article argues that 'restraining the recovery of certain types of loss"77 is merely one facet of the rationale behind the 'no reflective loss' rule, not the sole rationale. Johnson indicates that 'the fundamental issue for the operation of the no reflective loss rule is

\footnotetext{
${ }^{69}$ Atlasview (n 12) [63] (Jonathan Crow).

70 ibid.

${ }^{71}$ Hannigan (n 18) 615; Little Olympian Each Ways Ltd, Re [1995] 1 BCLC 636.

72 Payne, 'Sections 459-461 Companies Act 1985 Influx' (n 15) 668.

${ }^{73}$ Hannigan (n 18) 616.

74 ibid.

${ }^{75}$ Hirt (n 16) 109.

${ }^{76}$ Refer text to (n 69).

${ }^{77}$ Gardner v Parker [2004] EWCA Civ 781, [2005] BCC 46 [49] (Neuberger LJ).
} 


\section{Reconceptualising Shareholder Remedies to Mitigate the Problems Caused by the Overlap Between Section 994 and Part 11 Companies Act 2006}

whether the company has a cause of action'; if it does then 'its claim will always trump that of the shareholder'. ${ }^{78}$ Thus, the 'no reflective loss' rule goes beyond the need to avoid double recovery and is 'more rooted' in the Foss rule and applies even if there is no risk of double recovery. ${ }^{79}$ Therefore, where the court disapplies the "no reflective loss' rule when ordering a personal remedy to compensate a corporate loss, it discards the proper plaintiff rule in Foss. Consequently, the Salomon principle is undermined as the remedy for the wrong done to the company is not directed towards the injured party, namely, 'the body corporate' ${ }^{80}$ Thereby, the deputy judge appears to have appreciated one aspect of the rationale underlying the 'no reflective loss rule' while wholly ignoring the operating logic behind the rule, that an individual must not be recompensed for a loss sustained by another. ${ }^{81}$

Fourthly, the article argues that where the shareholder opts for a personal remedy to recover his fraction of the reflective loss, ${ }^{82}$ and there is no claim commenced by or on behalf of the company, the law fails to cure the loss endured by the company. To entirely recover the loss caused by the corporate wrong then, each shareholder must bring similar personal claims for the same corporate wrong to recover their fraction of reflective loss. The article disagrees with Jonathan Crow's argument that 'requiring the shareholder to follow the derivative action route at the end of s.994 is cumbersome' ${ }^{83}$ The article asserts that subsequent petitions by individual shareholders to recover their fraction of reflective loss would lead to an inconvenient and inefficient multiplicity of litigation in relation to the one wrong, proving to be costlier than if the court required a derivative action to be commenced. ${ }^{84}$ This outcome directly contradicts the aims of the Law Commission's 'Shareholder Remedies Reform Proposal' which sets out efficiency and cost-effectiveness as one of the six guiding principles in the consultation paper. ${ }^{85}$ The problem of efficiency, however, may be resolved through case management and procedural rules promoting the consolidation of all shareholders as respondents to one

\footnotetext{
${ }^{78}$ Johnson (n 44) [66].

79 ibid [65]-[68]; Day (n 42) [15]; Baring Plc v Cooper \& Lybrand (No.1) [2002] 1 BCLC 364.

${ }^{80}$ CA 2006, s 16.

${ }^{81}$ Johnson (n 44) [36].

${ }^{82}$ Hannigan (n 18) 616.

${ }^{83}$ Atlasview (n 12) [62].

${ }^{84}$ Hannigan (n 18) 616.

${ }^{85}$ Law Commission of England and Wales, 'Shareholder Remedies: Consultation Paper' (1997) CP142, [14.11] (Law Commission: Consultation Paper).
} 
petition. ${ }^{86}$ Nevertheless, in circumstances where shareholders lack the resources to bring a personal claim, justice for the corporate wrong will be denied altogether.

Lastly, the article raises the key concern that 'depending on the company's solvency, ${ }^{87}$ the issue of creditor protection in the context of ordering personal relief for corporate wrongs is a serious concern. ${ }^{88}$ Creditor protection in circumstances where the company is solvent is not problematic as the creditors will continue to get paid ordinarily. ${ }^{89}$ If the company is insolvent, the creditors' interests will not be under threat from a petition, for the court simply would not make a purchase order where the essence of the allegations relate to breaches of directors' duties for that would clearly breach the order of distribution on insolvency. ${ }^{90}$ The concern arises where the company is in the vicinity of insolvency as ordering personal relief will directly and adversely affect the creditors' ability to recover the sums due to them. ${ }^{91}$ If the court adheres to proper practice, a derivative claim provides relief for the benefit of the company where its creditors have the foremost claim on its funds. In contrast, a purchase order ensures that the payment goes directly from the wrongdoer to the petitioner. ${ }^{92}$ Applying the precedent created in Atlasview in circumstances where the company is in danger of insolvency, entirely undermines creditors' interests as 'the money due to the company bypasses its coffers and goes straight into the shareholders' pockets instead'. ${ }^{93}$

\section{Proposed Solution: An Authoritative Framework}

Aiming to mitigate the predicaments in subsection 2, subsection 3 proposes an authoritative framework for the courts to apply in circumstances where a shareholder seeks personal relief for a corporate wrong. Step one involves the court determining in the preliminary hearing stage whether the director's duty was owed to a) 'the company alone', b) 'the shareholder alone' or c) 'both the company and the shareholder'. Where the director owes a duty to the 'shareholder alone', the position is clear: a claim for personal relief will be well justified. Where the court ascertains that the 'director owes his duty to the company alone', it must abide by the proper plaintiff rule and require

\footnotetext{
${ }^{86}$ Company (No.007281 of 1986), Re [1987] BCLC 598-599 Ch D ; The Companies (Unfairly Prejudicial Applications) Proceedings Rules 1986 (SI 1986/2000).

${ }^{87}$ Joyce Lee Suet Lin, 'Barring recovery for diminution in value of shares on the reflective loss principle' (2007) 66(3) C.L.J. 537, 556; Hannigan (n 18) 617-18.

88 ibid.

${ }^{89}$ Hannigan (n 18) 617-18.

${ }^{90}$ Hailey Group Ltd, Re [1993] BCLC 459 Ch D [473].

${ }^{91}$ Hannigan (n 18) 618; McAskill v Fulton (2014) WL 8106597 [45] (Norris J).

${ }^{92}$ Ellis Ferran, 'Case Comment: Litigation by shareholders and reflective loss' (2001) 60(2) C.L.J. 245.

${ }^{93}$ Chime Corp (n 24) [25] (Bokhary PJ); Johnson (n 44) [366] (Lord Millett).
} 


\section{Reconceptualising Shareholder Remedies to Mitigate the Problems Caused by the Overlap Between Section 994 and Part 11 Companies Act 2006}

that 'only the company may sue in respect of the loss sustained'. ${ }^{94}$ Alternatively, a derivative claim may lie under Pt 11 CA 2006.

The only exception to the blanket bar for 'a personal claim by a shareholder in respect of a reflective loss' lies where a 'company sustains a loss but lacks a cause of action' ${ }^{95}$ In those circumstances, a member of the company who has a cause of action can bring a claim to recover the loss regardless of whether the loss is a reduction in the value of the shareholding. ${ }^{96}$ The justification for allowing recovery in such circumstances is that the shareholder who exercises his cause of action against the director does not unjustly enrich himself at the expense of causing prejudice to the other members of the company. In effect, where the company lacks a cause of action, the shareholder's action cannot reduce the company's asset value. ${ }^{97}$ Thereby, the second predicament discussed in subsection 2, that a shareholder's personal claim reduces the value of the company's claim against the director, is discarded altogether. ${ }^{98}$ An example of an instance where 'the company lacked a cause of action' is perceived in Giles $v$ Rhind. ${ }^{99}$ In that case, the breach of duty by the wrongdoer was so severe that it 'disabled the company' from continuing its cause of action as the company was unable to afford security for costs. The fact that the company decided not to claim against the defendant does not suffice. ${ }^{100}$ Additionally, a shareholder may be permitted to commence a claim to secure personal relief for a breach of directors' duties where he successfully establishes that the loss claimed for is 'separate and distinct' from the loss endured by the company. ${ }^{101}$ In those circumstances, both the company and shareholder may recover only the loss sustained by them separately; neither must be allowed to recover losses endured by the other. ${ }^{102}$

In effect, step one mitigates the third predicament discussed in subsection 2 regarding the rule in Foss and the Salomon principle because it firmly reasserts that the proper plaintiff in relation to a wrong done to the company is prima facie the company. In sum, step one allows a shareholder to maintain a claim for personal relief in relation to a corporate wrong in two circumstances. First, where the director's duty is owed to

\footnotetext{
${ }^{94}$ Johnson (n 44) [35].

95 ibid.

96 ibid.

${ }^{97}$ Lee $v$ Sheard [1956] 1 QB 195-96.

${ }^{98}$ Refer text to (n 75).

99 [2002] EWCA Civ 1428.

${ }^{100}$ Gardner (n 77).

101 Johnson (n 44) [35]-[36].

102 ibid.
} 
the company, but the 'company lacks a cause of action'. Secondly, where the shareholder establishes that the loss is 'separate and distinct' from the company's loss. In both circumstances, the shareholder is exercising his personal right to a claim and not assuming the right of the company to bring a claim. Although the task of ascertaining to whom the duty is owed may seem to be fairly straightforward, in practice, it is a difficult task, especially since the breach of directors' duties may be construed as a wrong to the entity and the shareholder. ${ }^{103}$ Notwithstanding the difficulty involved in categorising the cases owing to the factual overlap, the article submits that the courts must 'theoretically' distinguish between a breach of duty owed to the 'company' and the 'shareholder'. ${ }^{104}$ If the courts ignore the 'theoretical basis for the distinction', then all claims by shareholders for infringement of their personal rights will also found a derivative action, a position which is unsustainable under company law. ${ }^{105}$

Where step one is surpassed, step two involves examining the nature of the loss sustained by the claimant. During the examination, the court must maintain the position that, as a fundamental rule, petitioners cannot recover reflective loss. The starting point lies in Lord Bingham's formulation in Johnson. ${ }^{106}$ The court should 'ascertain if the loss in question appears to be or is one which would be made good if the company had enforced its full rights against the director'. ${ }^{107}$ In effect, the test requires the court to determine whether the loss suffered is a 'personal loss' and not a 'corporate loss'. The article proposes that where a loss is classified as a personal loss, the court must further determine if it is a 'mere personal loss' which translates into a reflective loss. Alternatively, the court must examine whether the personal loss is a loss 'separate and distinct' from the loss endured by the company.

The article submits that, where the loss in question involves a 'diminution in the value of a petitioner's shareholding' caused by the breach of directors' duties, the courts must classify such a loss as a 'mere personal loss' which translates into a reflective loss. ${ }^{108}$ The article focuses on the concept of 'shares' and 'shareholding' to arrive at this deduction. Unfortunately, the concept of 'shares' and 'shareholding' remain

\footnotetext{
${ }^{103} \operatorname{Lin}(\mathrm{n} 87) 547$.

${ }^{104} \operatorname{Lin}(\mathrm{n} 87) 548$.

105 Dan Prentice, 'The Theory of the Firm: Minority Shareholder Oppression: Sections 459 - 461 of the Companies Act 1985' (1988) 8 O.J.L.S. 55, 67.

106 Johnson (n 44).

107 Johnson (n 44) [36].

108 Johnson (n 44) [44] (Lord Hutton), [53] (Lord Millett).
} 


\section{Reconceptualising Shareholder Remedies to Mitigate the Problems Caused by the Overlap Between Section 994 and Part 11 Companies Act 2006}

inexact, ${ }^{109}$ and the precise 'juridical nature' of the 'share' is a burdensome examination. ${ }^{110}$ On the one hand, there is a school of thought led by Pennington which emphasises 'a purely contractual definition of a share'. ${ }^{111}$ On the other hand, Gower and Davies forms a school of thought which takes the position that the rights conferred by shares are 'not purely personal rights'. Instead, 'some proprietary interest' in the company is conferred upon the shareholder. ${ }^{112}$ This article supports the most practical view that 'shares are recognised as the property of the shareholder'. ${ }^{113}$ The deduction extracted from the supported view is that 'a diminution in value of the shares is a damage to the shareholder's personal property' and therefore, is a personal loss. ${ }^{114}$ Despite this conclusion, the important point as Lord Millett puts it is, 'this personal loss is reflective of the company's loss; recovery of the loss by the company would redress the shareholder's loss'. ${ }^{115}$ Lord Millett's position assumes that in private companies there exists a perfect positive correlation between 'the diminution in the value of the company's assets' and 'the diminution in the value of the shares'. ${ }^{116}$ However, it is unclear if the correspondence is indeed exact. For example, the wrongdoing may negatively affect the 'calculation of goodwill' in the sense of the 'the potential the business had', ${ }^{117}$ which is a concept broader than is encompassed by future 'revenue' or 'net profits'. ${ }^{118}$ However, quantifying losses in the sense of 'the potential the business had' is a vague task due to the uncertainties of the term 'potential'. Therefore, the article maintains the stance that a claim for 'diminution in value of the shares' resulting from 'a breach of directors' duties' is a classic example of a 'mere personal loss' and must be struck out as contrary to the 'no reflective loss' rule.

An example of a loss that is 'separate and distinct' from a company's loss was put forward by the court in the Prudential case. Where a director summons a meeting based on a fraudulent circular, shareholders can recover any loss personally suffered as

\footnotetext{
${ }^{109}$ Paddy Ireland, 'Company Law and the Myth of Shareholder Ownership' (1999) 62 MLR 32, 44.

${ }^{110}$ P L Davies and L C B Gower, Principles of Modern Company Law (7th ed, London: Sweet \& Maxwell2003) 615.

${ }^{111}$ Roberty Pennington, 'Can Shares in Companies be Defined?' (1989) 10(7) The Company Lawyer 140, 144; Borland's Trustee v Steel Bros \& Co Ltd [1901] 1 Ch 288; Lord Hailsham of St. Marylebone (ed), Halsbury's Laws of England vol 7(1) (4th ed, 1991) 414.

112 Davies and Gower (n 110) 616.

113 Pilmer v Duke Group Ltd [2002] 2 BCLC 784.

${ }^{114} \operatorname{Lin}(\mathrm{n} 87) 542$.

115 Johnson (n 44) [66].

116 Johnson (n 44) [62].

117 Giles (n 99) [28] (Waller LJ).

${ }^{118}$ Lin (n 87) 551.
} 
a consequence, which may include the expenditure incurred to attend the meeting. ${ }^{119}$ Additionally, the company may claim for the loss it endures because of the directors' fraudulent conspiracy. ${ }^{120}$ Denying personal relief for 'mere personal loss' claims mitigates the first predicament regarding double recovery by the shareholder discussed in subsection 2 because the shareholder is barred from personally recovering the reflective loss. ${ }^{121}$ In conclusion, those shareholders who cannot establish a 'separate and distinct' loss, would have to follow the derivative action route to obtain relief. ${ }^{122}$ On the outset, it may appear that requiring a shareholder to commence a derivative action is cumbersome. On balance, however, requiring shareholders to follow a derivative claim in circumstances where they cannot establish a 'separate and distinct' loss will mitigate the fourth and fifth predicaments discussed in subsection $2 .{ }^{123}$ In effect, a derivative claim will ensure the company is not denied redress for the wrong done to it and the creditors' interest in circumstances where the company is potential of insolvency will be safeguarded.

\section{S.994 CORPORATE RELIEF FOR A CORPORATE CLAIM}

The conventional paradigm relating to shareholder remedies holds that corporate wrongs must be prosecuted for judgment through the derivative claim route. ${ }^{124}$ Contrary to the standard view, case law shows that where the alleged wrong is the breach of directors' duties owed to the company (a classic corporate wrong), s.994 has been used to secure a remedy for the company. ${ }^{125}$ This consequence has triggered much academic debate. ${ }^{126}$ Shareholders employ s.994 in two ways to seek corporate redress. Firstly, they do so to obtain corporate relief. ${ }^{127}$ Second, they use the section to obtain the

\footnotetext{
${ }^{119}$ Prudential (n 6) 222.

120 ibid.

${ }^{121}$ Refer text to (n 69), (n 70) and (n 72).

122 Payne, 'Sections 459-461 Companies Act 1985 Influx' (n 15) 669.

${ }^{123}$ Refer text to (n 82), (n 84), (n 87), (n 88) and (n 93).

124 Stephen Bottomley, The Constitutional Corporation (Ashgate, 2007), 167.

${ }^{125}$ Clark v Cutland [2003] EWCA Civ 810, [2003] 2 BCLC 393; Anderson v Hogg [2002] BCC 923; Bhullar v Bhullar [2003] EWCA Civ 424, 2 BCLC 241; Gamlestaden Fastigheter AB v Baltic Partners Ltd [2008] 1 BCLC 468 PC (Jersey).

126 Jeffrey Macintosh, 'The Oppression Remedy: Personal or Derivative?' (1991) 70 Canadian Bar Review 29; John Lowry, 'Reconstructing Shareholder Actions: A Response to the Law Commission's Consultation Paper' (1997) 18(8) The Company Lawyer 247, 255; Jill Poole and Pauline Roberts, 'Shareholder Remedies--Corporate Wrongs and the Derivative Action' (1999) JLB99; Edward M. Iacobucci and Kevin E. Davis, 'Reconciling Derivative Claims and the Oppression Remedy' (2000) 12 Supreme Court Law Review 87.

${ }^{127}$ Clark v Cutland [2003] EWCA Civ 810, [2003] 2 BCLC 393; Anderson v Hogg [2002] BCC 923; Bhullar v Bhullar [2003] EWCA Civ 424, 2 BCLC 241; Gamlestaden Fastigheter AB v Baltic Partners Ltd [2008] 1 BCLC 468 PC (Jersey).
} 


\section{Reconceptualising Shareholder Remedies to Mitigate the Problems Caused by the Overlap Between Section 994 and Part 11 Companies Act 2006}

authorisation of a derivative claim as the outcome of a petition. ${ }^{128}$ At this point, it is essential to distinguish between the two forms of corporate redress. Corporate relief provides a 'definite and immediate recompense to the company'. ${ }^{129}$ By contrast, authorisation of a derivative claim 'puts the company through litigation that consumes both time and resources'. ${ }^{130}$ In effect, there is no guarantee of success of the litigation or the scope of the remedy that the court may finally offer. This section anchors the debate on the second problematic outcome generated by the overlap between the two remedies, namely, the use of s.994 to obtain corporate relief. Subsection 1 puts forward four cases to illustrate that courts have exercised their discretion to order corporate relief as the outcome of a petition instead of requiring the commencement of a derivative claim. Subsection 2 evaluates the drawbacks and benefits of accepting the unorthodox approach. Acknowledging that the practical advantages ameliorate some of the drawbacks, subsection 3 proposes a mitigating solution in the form of a middleground approach to the issue of ordering corporate relief under s.994.

\section{Corporate Relief Under S.994: Case Law}

In Clark $v$ Cutland, ${ }^{131}$ the director in breach of his fiduciary duties owed to the company, misappropriated the company's money. A derivative claim brought on behalf of the company for the recovery of the money was consolidated with the unfair prejudice petition. ${ }^{132}$ Interestingly, the order made on the petition was for the repayment of money to the company. Moreover, the court was willing to make a Wallersteiner order ${ }^{133}$ requiring the company to indemnify the petitioner's costs as would be the case in a derivative claim. ${ }^{134}$ The judgment in Cutland signifies two difficulties. First, the court unlocked the possibility for shareholders to indirectly enforce the company's rights, undermining the rule in Foss. ${ }^{135}$ Second, the court's willingness to make a Wallersteiner order inadvertently renders the petition as a superseding alternative to the derivative claim. ${ }^{136}$ The facts in Cutland are fundamentally similar to the facts in

\footnotetext{
${ }^{128}$ CA 2006, s s.996(2)(c).

129 Yap (n 25).

130 ibid.

131 [2003] EWCA Civ 810, [2003] 2 BCLC 393.

132 ibid 396.

${ }^{133}$ Wallersteiner v Moir [1975] QB 373, 1 All ER 849.

${ }^{134}$ Clark (n 131) 405.

135 Payne, 'Shareholders' Remedies Reassessed' (n 5); Rita Cheung, 'Corporate wrongs litigated in the context of unfair prejudice claims: reforming the unfair prejudice remedy for the redress of corporate wrongs' (2008) 29(4) The Company Lawyer 98, 100.

${ }^{136}$ Clark (n 131) [35].
} 
Bhullarv Bhullar. ${ }^{137}$ In Bhullar, the directors had obtained property in conflict with the fiduciary duties they owed to the company as directors. The Court of Appeal ordered corporate relief under the petition. Similarly, in Anderson v Hogg, ${ }^{138}$ the court, (based on a claim under a petition), ordered the payment to the company of money improperly transferred to a director. In Gamlestaden Fastigheter ABv Baltic Partners, ${ }^{139}$ the Privy Council (PC) dealing with the Jersey statutory equivalent of ss.994-996, ${ }^{140}$ contemplated on 'the role of s.994 in respect of claims arising out of breaches of directors' duties'. In Gamlestaden the PC did not grant corporate relief. However, the PC, applying the arguments made in the judgment of the Hong Kong Court of Final Appeal in Re Chime Corp Ltd, ${ }^{141}$ made the following clarifications: firstly, the unfair prejudice remedy can be used to 'enforce a cause of action vested in the company, arising out of breaches of directors' duties'; and secondly, the court could order that 'wrongdoing directors pay damages to the company' in those circumstances. ${ }^{142}$

The judgment in Gamlestaden leads to the inference that the precedent in Cutland, as extrapolated in Bhullar, that the expansive scope of s.994 allows for claims of corporate relief, is the prevailing stance on the issue at hand. ${ }^{143}$ The article submits that, with the codification of the derivative action under Pt 11 CA 2006, ordering corporate relief on a s.994 petition as a matter of following the precedent laid by Arden L.J in Cutland is an erroneous application of the law. Cutland, Bhullar, Anderson and Gamlestaden all share the commonality that they are 'pre-Pt 11 CA 2006' cases. ${ }^{144}$ Hannigan argues that as a result of this 'commonality' the petitioners in each case were, based on different grounds, precluded from commencing a derivative claim. ${ }^{145}$ However, because the claims in each case required a remedy, the court proceeded to do so under the guise of s.994. Indeed, had Gamlestaden come before the court when Pt 11 CA 2006 was in force, there is a plausible argument that the case would have advanced as a derivative claim because negligence can place such a claim under the

\footnotetext{
137 [2003] EWCA Civ 424, 2 BCLC 241.

138 [2002] BCC 923.

139 [2008] 1 BCLC 468 PC (Jersey).

140 Companies (Jersey) Law 1991, art 141.

${ }^{141}$ Chime Corp (n 24).

142 Adrian Walters, 'Case Comment: s. 459, “Shareholder” or "Investor Remedy”?' (2007) 28(10) The

Company Lawyer 289; Tony Singla, 'Case Comment: Unfair Prejudice in the Privy Council' (2007) 123

L.Q.R. 542.

${ }^{143}$ Gray (n 7) 298.

${ }^{144}$ Hannigan (n 18) 623.

145 ibid.
} 


\section{Reconceptualising Shareholder Remedies to Mitigate the Problems Caused by the Overlap Between Section 994 and Part 11 Companies Act 2006}

statutory footing. ${ }^{146}$ In respect of Bhullar and Anderson, Hannigan asserts that the two cases are evidently derivative actions, 'in substance and outcome' but proceeded improperly under a petition. ${ }^{147}$ Furthermore, the article asserts that Arden LJ in Cutland interprets the petition 'expansively' without providing reasons to interpret in such a way. Payne argues that, although Arden LJ's judgment lacks reasoning, persuasive reasons are available for the decision. ${ }^{148}$ The article submits that automatically accrediting such reasoning to Arden LJ is conjectural and implausible. ${ }^{149}$ Thus, the article asserts that these cases may be viewed as 'exceptional' in nature and must not be viewed as the courts providing a 'criteria for ordering corporate relief on a petition'. 150

\section{Impact of Accepting the Unorthodox Approach}

The first argument against ordering corporate relief under s.994 is that it undermines the policy underpinning the rule in Foss. The underlying policy of the composite rule in Foss is sound. Viz., companies are 'collective' associations, and therefore 'the decision of whether or not to litigate in respect of wrongs done to the company' should be 'left to the majority except where the wrongdoers are themselves in control'. ${ }^{151}$ As Gray argues, widening the scope of s.994 contradicts the policy underpinning the rule in Foss because the 'decision to litigate' is taken by an individual member, not the company. ${ }^{152}$ In discarding the proper plaintiff rule, the courts risk abandoning the foundational principle underpinning company law, that a company is a distinct legal entity. ${ }^{153}$ The codification of the derivative action under Pt 11 CA 2006 may suggest to some that the significance of the rule in Foss has faded. However, the authoritative stance is that the derivative action under the statutory footing further strengthens the rule in Foss. Parliament's requirement that a shareholder must secure the court's permission to continue a derivative action under Pt 11 CA 2006 acts as a hefty hurdle in the way of a claimant; thus, it protects the rule in Foss. ${ }^{154}$ More explicitly, the 'Explanatory Notes to the CA 2006' read that the provisions in Pt 11 do not intend to

\footnotetext{
${ }^{146}$ CA 2006 s.260(3); Refer text to (n 37).

${ }^{147}$ Hannigan (n 18) 623; Anderson (n 138) [934] (Lord Prosser).

148 Payne, 'Shareholders' Remedies Reassessed' (n 5) 501.

149 Gray (n 7) 299.

${ }^{150}$ Chime Corp (n 24) [27].

${ }^{151}$ DTI: Developing the Framework (n 21) [4.19], [4.67].

152 Gray (n 7) 299.

${ }^{153}$ Salomon (n 32).

${ }^{154}$ DTI Final Report (n 36) [7.46]-[7.48].
} 
replace the rule in Foss. ${ }^{155}$ Therefore, in circumstances where the Parliament has reasserted the commitment to safeguard the rule in Foss, the courts' acceptance of using s.994 to order corporate relief which openly undermines the rule in Foss, is puzzling. ${ }^{156}$

The second argument against ordering corporate relief under s.994 is that the courts risk rendering the derivative action obsolete, with s.994 destined to remain the 'remedy of choice among shareholders'. ${ }^{157}$ Section E(2) below conducts a detailed evaluation of the need to safeguard the derivative jurisdiction. However, for the purpose of this section, the article submits that rendering the derivative action obsolete is a regressive step. The article appreciates the view of academics that the derivative action is a mechanism that reduces agency costs of a company. ${ }^{158}$ The derivative actions assist in deterring directorial wrongdoing and help maintain investor confidence by providing an effective entry to the courts. ${ }^{159}$ Finally, the article argues that ordering corporate relief under s.994 is an unwelcome development for companies because, notwithstanding their 'exceptional facts', ${ }^{160}$ the outcomes of the cases discussed in subsection 1 can unlock floodgates to unwarranted litigation by minority shareholders and enhance the risk of abuse of process.

These shortcomings lead to the conclusion that the courts must abide by the orthodox derivative action approach to resolve corporate claims, rather than seeking equivalent relief through a more circuitous route. ${ }^{161}$ However, the practical advantages that follow from allowing shareholders to obtain corporate relief on a petition negate this conclusion. To put it simply, ordering corporate relief following a successful petition, instead of requiring the shareholder to commence a derivative action, prevents the unnecessary duplication of proceedings. ${ }^{162}$ Academics such as Cheung assert that ordering corporate relief directly under the petition is an eminently pragmatic and

\footnotetext{
155 Explanatory Notes to the Companies Act 2006, para 483; Yap (n 25) 151.

156 Paul Davies, Gower's Principles of Modern Company Law (6th ed Sweet \& Maxwell, 1997) 738; Francis Beaufort Palmer and Geoffrey Morse, Palmer's Company Law (25th ed Sweet \& Maxwell, 1992) 8.904.

${ }^{157}$ Cheffins (n 22).

158 Richard Posner, Economic Analysis of Law (3rd edn, Little Brown 1986) 389.

159 Coffee and Schwartz, 'The Survival of the Derivative Suit: An Evaluation and a Proposal for Legislative Reform' (1981) 81 Colum.L.Rev. 261, 302-309; Kaplan and Elwood, 'The Derivative Action: A Shareholder's "Bleak House?”' (2003) UBC Law Rev. 443, 451, 455.

${ }^{160}$ Hannigan (n 18) 624.

161 James Watson, 'Case Comment: Unfair prejudice against an insolvent company' (2007) 20(9) Insolvency Intelligence 141, 141-42.

${ }^{162}$ Re a Company [1986] 1 WLR 281 [284d-h] (Hoffmann J).
} 


\section{Reconceptualising Shareholder Remedies to Mitigate the Problems Caused by the Overlap Between Section 994 and Part 11 Companies Act 2006}

sensible conclusion that will expedite matters and prove to be cost-effective. ${ }^{163}$ Thus, in subsection 3 the article aims to build in a proper mechanism for the court to follow when allowing a shareholder to indirectly enforce the company's rights under s.994. ${ }^{164}$

\section{The Middle-Ground Solution}

The opening statement of this section is that the precedent in Cutland that allows the court to automatically order corporate relief upon establishing the criteria of the petition must be swept away. The article combines the findings from two cases to create a legal framework for the courts to follow in circumstances where a shareholder seeks to obtain 'corporate relief' under the 'petition' in respect of 'an infringement of the company's rights'. ${ }^{165}$ The two cases significant to the legal framework are Charnley Davies ${ }^{166}$ and Chime Corp. ${ }^{167}$ The starting point lies in Lord Millett's remarks (albeit obiter) in Charnley Davies. ${ }^{168}$ The case concerned 'a petition under s.27 Insolvency Act 1986', which mirrors the remedy under s.994, 'for creditors and members in situations where an administration order is in force'. The first step obliges the court, at the 'pleading stage', to concentrate on what is 'the whole gist of the complaint'. ${ }^{169}$ According to Lord Millett, the court must examine 'the whole gist of the complaint' to understand whether the unlawful conduct in question is, in essence, a 'misconduct' or a 'mismanagement'. Simply described, 'misconduct' translates to 'unlawful conduct such as a breach of duty'. ${ }^{170}$ 'Mismanagement' falls under a wider category of unlawful conduct which could consist of misconduct 'in part but not in whole'. ${ }^{171}$

In the opinion of Lord Millett, where 'the whole gist of the complaint' represents misconduct alone, the case must be dealt with by a derivative action. ${ }^{172}$ Thus, where 'the whole gist of the complaint' does not represent misconduct entirely but could include misconduct in part, the unlawful conduct can be ascertained as a

\footnotetext{
163 Rita Cheung, 'Corporate wrongs litigated in the context of unfair prejudice claims: reforming the unfair prejudice remedy for the redress of corporate wrongs' (2008) 29(4) The Company Lawyer 98, 100.

${ }^{164}$ John Lowry, 'Reconstructing Shareholder Actions: A Response to the Law Commission's Consultation Paper' (1997) 18(8) The Company Lawyer 247, 255; Jill Poole and Pauline Roberts, 'Shareholder Remedies--Corporate Wrongs and the Derivative Action' (1999) JBL 99, 119-21.

165 Geof Stapledon, 'Use of the Oppression Provision in Listed Companies in Australia and the United Kingdom' (1993) 67 ALJ 575, 576.

${ }^{166}$ Charnley (n 8) [783].

${ }^{167}$ Chime Corp (n 24) [62]-[63].

${ }^{168}$ Charnley (n 8) [783].

169 ibid.

${ }^{170}$ Chime Corp (n 24); Gray (n 7) 298.

171 ibid.

${ }^{172}$ Charnley (n 8).
} 
'mismanagement'. Lord Millett states that a petition is justified where the claim involves loss sustained as a result of mismanagement by directors, but only to provide personal relief for the petitioner, not corporate relief for the company. ${ }^{173}$ According to his Lordship, 'the distinction between misconduct and mismanagement does not lie in the particular acts or omissions of which the complaint is made, but in the nature of the complaint and the remedy necessary to meet it'. ${ }^{174}$ His Lordship's proposition is important because it recognises that there may be more than one legal dimension, either a derivative claim or a s.994 petition, to the same set of facts. Although the same set of facts can establish two separate remedial claims, Lord Millett asserts that 'the nature of the complaint' and 'the appropriate relief' are distinctive in the two instances. ${ }^{175}$

Upon categorising the unlawful conduct as either misconduct or mismanagement, the subsequent step involves utilising Lord Scott's judgment in Chime Corp. The provision under consideration in the Hong Kong case Chime Corp mirrors s.994 in all relevant aspects, and the judgments of Justice Bohkary P.J. and Lord Scott (with whom the rest of the court agreed) entailed a complete review of the English authorities. In essence, Lord Scott endorses and builds upon Lord Millett's distinction between 'misconduct claims' and 'mismanagement claims'. In doing so, Lord Scott opined that the use of a petition 'in order to circumvent the rule in Foss in a case where the nature of the complaint is misconduct rather than mismanagement is, an abuse of process'. ${ }^{176}$ Following Lord Scott's judgment, upon categorising a claim as one of mismanagement, it is possible for the court to exercise their discretion and order corporate relief under the petition provided the following two hurdles be surpassed. Firstly, it must be possible to determine the quantity of the director's liability at the pleading stage. ${ }^{177}$ Secondly, the relief to be ordered must correspond with the redress which the company could have secured had it sued or if a derivative claim was established. ${ }^{178}$ Support for including the hurdle stage in the legal framework is found in Gower's statement that 'the decision of Lord Scott in Chime Corp is based on the correct principles and should be followed'. ${ }^{179}$

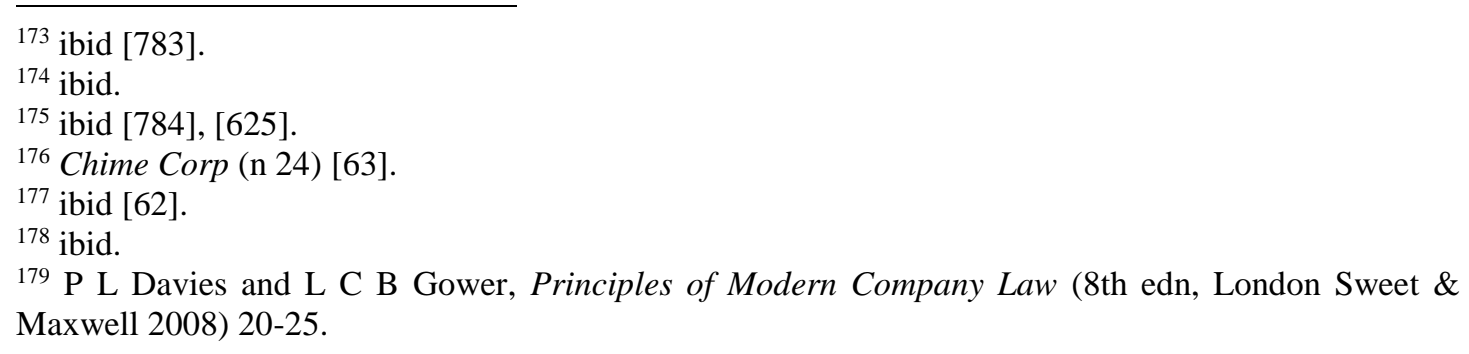




\section{Reconceptualising Shareholder Remedies to Mitigate the Problems Caused by the Overlap Between Section 994 and Part 11 Companies Act 2006}

While the legal framework appears imprecise, the article submits that it is evidently workable. Applying the framework to Anderson, Bhullar and Gamlestaden, it is clear that the whole gist of the complaints (breach of directors' duties) was misconduct and therefore a derivative claim was the appropriate way forward. ${ }^{180} \mathrm{On}$ the other hand, Cutland is an example of mismanagement, and in this case Lord Scott's criteria in Chime Corp come into play. Hannigan affirms that the question of whether the directors' liability can be conveniently ascertained at the pleading stage in Cutland is straightforwardly answered. In effect, when assessing the conduct of the company's affairs to establish a petition, the court in Cutland had to examine the "manner and circumstances in which the director had extracted money' from the company. ${ }^{181}$ Therefore, determining the value of the director's liability upon quantifying the loss endured by the company at the pleading stage of the petition was a convenient task. In effect, the legal framework attempts to safeguard the rule in Foss by requiring claims involving misconduct and mismanagement claims that cannot surpass Lord Scott's criteria to be resolved through a derivative action. Consequently, the derivative claims are not rendered obsolete. The need to surpass Lord Scott's criteria of quantifying the directors' liability at the pleading stage would negate the floodgate argument raised in subsection 2. Undoubtedly, however, a Supreme Court verdict on the debate would be a positive development.

\section{E. AUTHORISING A DERIVATIVE CLAIM VIA S.994}

In section $\mathrm{D}$ the article distinguished between the two forms of corporate redress sought by shareholders as the outcome of the petition. ${ }^{182}$ Section E aims to illustrate that the authorisation of a derivative claim as the outcome of a petition, is yet another undesirable consequence that stems from the overlap between the two remedial jurisdictions. In essence, where an alleged breach of directors' duties forms the basis of a successful petition, s.996(2)(c) and s.260(2)(b) CA 2006 collaboratively provide that the court may exercise its discretion to authorise a derivative claim as the outcome of a petition. For example, in Shun Tak Holdings Ltd, Re, ${ }^{183}$ the remedy sought in an unfairly prejudicial petition brought under the unfair prejudice provisions in the Hong Kong

\footnotetext{
${ }^{180}$ Hannigan (n 18) 624.

181 ibid 625.

182 Refer text to (n 129), (n 130) in section D.

183 [2009] 5 HKLRD 743.
} 
Companies Ordinance, ${ }^{184}$ included an order authorising a derivative claim against its directors for their alleged breaches of duty. In subsection 1 the article raises a grave policy concern to assert that the existence of two parallel regimes for authorising derivative actions is problematic. In subsection 2 the article critically evaluates two proposals to resolve the problems identified in subsection 1. Finally, with the objective of mitigating the problematic consequences of the overlap in context, subsection 3 puts forward a reform proposal that establishes a middle-ground solution.

\section{Authorising a Derivative Claim Through S.994: The Predicaments}

As section B(2) above illustrates, Pt 11 CA 2006 necessitates the shareholder to obtain the court's permission in two stages to 'continue' a derivative action under the 2006 Act. ${ }^{185}$ In sum, the principal question considered in the permission stages is 'whether it is in the interest of the company as a whole that the claim is pursued'. ${ }^{186}$ In apparent contrast to the position under Pt 11 CA 2006, the grounds on which derivative actions may be authorised under the petition do not expressly include considerations relating to the company's best interest. The over-arching consideration as stated in s.996(1) CA 2006 is that the order should give relief for the unfairly prejudicial conduct in context. ${ }^{187}$ Thus, when authorising a derivative action as the outcome of a petition, the court focuses not on the question whether the continuance of a derivative claim will promote the interest of the company, but whether it provides a remedy that relieves the prejudiced shareholder. ${ }^{188}$ Therefore, the two regimes have different threshold tests to obtain the authorisation of a derivative action.

The article concedes Kershaw's argument that the ability to authorise a derivative action as the outcome of a petition is problematic because it effectively circumvents the hurdles that have been carefully crafted in Pt 11 CA $2006 .{ }^{189}$ The question then is, as Louis Doyle and MR Justice David Richards contend, whether the permission stages enacted by the Parliament in Pt 11 CA 2006 has any importance if petitioners are allowed to circumvent them by 'getting around and in through the back door'? ${ }^{190}$ The article acknowledges that where a derivative action is authorised via

\footnotetext{
${ }^{184}$ Hong Kong Companies Ordinance, s 168A.

${ }^{185}$ Refer section $\mathrm{B}(2)$.

186 ibid.

${ }^{187}$ Refer section B(3).

188 Yap (n 25) 152.

189 Joan Loughrey, Directors' Duties and Shareholder Litigation in the Wake of the Financial Crisis (Edward Elgar 2013), 235.

190 ibid 236.
} 


\section{Reconceptualising Shareholder Remedies to Mitigate the Problems Caused by the Overlap Between Section 994 and Part 11 Companies Act 2006}

s.994, it effectively bypasses a 'time consuming and expensive mini-trial' at the permission stage. ${ }^{191}$ Moreover, Loughrey's literature review on the issue at hand profoundly recognises Keay's contention that the threshold to pass the 's.261(2)- prima facie case' hurdle is to establish a more than a zero per cent chance. ${ }^{192}$ The article accredits Loughrey's acknowledgment of Gibbs' scepticism as to the significance of the first permission stage, because a 'more than zero per cent' threshold can easily be surpassed. ${ }^{193}$

Nevertheless, the article submits that the authorisation of a derivative action as the outcome of a petition defeats the policy reasons for establishing the permission stages in Pt 11 CA 2006 in the first place. The Parliament included the prima facie test in the statutory derivative procedure to 'avoid opening floodgates to every disenchanted individual in the country'. ${ }^{194}$ In effect, Parliament required the courts to 'filter out unmeritorious or flimsy claims without the participation of companies and at the earliest possible opportunity'. ${ }^{195}$ Franbar v Patel ${ }^{196}$ and Stimpson v Southern Landlords Association ${ }^{197}$ are classic examples of Parliament's intention in placing the hurdles being rightly executed. In both cases, the courts exercised their discretion to refuse permission because the continuance of the claims was not actually 'in the interests of the company'. Therefore, the article submits that the s.994 regime of authorising derivative actions which do not have a filtering stage would be a prima facie welcome development 'only in a world where members never raise vexatious, wholly malicious or unmeritorious actions'. 198

In addition to the policy argument, the article contends that the authorisation of a derivative claim under s.994 is also problematic because it discards the majority rule in Foss. Pt 11 CA 2006 and the Explanatory Notes to the CA 2006 safeguards the majority rule in Foss as 'ratification or authorisation by the company of the conduct complained of' is a bar to a derivative claim. ${ }^{199}$ In contrast, the court is not expressly required to consider issues of ratification or authorisation by the company when authorising a derivative claim under s.994. Therefore, in the absence of the permission

\footnotetext{
${ }^{191}$ Law Commission, Shareholder Remedies (Law Com No 246, 1997) para 6.71.

192 Loughrey (n 189) 237.

193 ibid.

${ }^{194}$ HL Deb 9 May 2006, vol 681, col 885 (Lord Sharman); Tang (n 26).

195 HL Deb 9 May 2006, vol 681, col 883 (Lord Goldsmith).

${ }^{196}$ Franbar v Patel [2008] EQHC 1534 (Ch); [2008] BCC 885.

${ }^{197}$ Stimpson v Southern Landlords Association [2009] EWHC 2072 (Ch).

198 Gray (n 7) 296.

${ }^{199}$ CA 2006, s 263(2)(c); Explanatory Notes to the Companies Act 2006, para 483.
} 
stages which consider the issues of ratification or authorisation, the majority rule in Foss is discarded under s.994 as under s.994 the petitioner decides 'whether or not to litigate', not the company. ${ }^{200}$

\section{Analysis of Two Possible Solutions}

In response to the policy concerns relating to different threshold tests and the disquiet of disregarding the majority rule in Foss (that arises where a derivative claim is authorised as the outcome of a petition), the article contemplates two solutions. The first solution is to abolish the court's power under s.996(2)(c) CA 2006 to authorise a derivative claim as the outcome of a petition, effectively confining the derivative actions within Pt 11 CA 2006 jurisdiction. The second solution is to abolish the derivative claim jurisdiction under Pt 11 CA 2006, respecting s.994 as the equivalent alternative to the Pt 11 CA 2006 derivative jurisdiction.

The principal argument in respect of the first solution, viz., the removal of the power under s.996(2)(c) to authorise derivative claims as the outcome of a petition is that it will effectively streamline the framework of the CA 2006 as derivative actions will be covered exclusively in $\mathrm{Pt} 11 .^{201}$ Consequently, the law relating to derivative claims would have greater certainty and it would reduce wasteful litigation. Moreover, the mandatory requirement that a petitioner under s.994 must prove that 'unfairly prejudicial conduct has occurred ${ }^{202}$ exceeds what is required of an orthodox derivative claimant. An orthodox derivative claimant simply needs to establish that a company has endured a loss as a result of a wrong complained of and that the pursuance of a claim in respect of that loss is 'in the best interest of the company'. Posit a setting where the solution of abolishing the court's power under s.996(2)(c) CA 2006 is implemented, then misfortunate outcomes of cases such as in Shun Tak, where claimants were informed after a time-consuming trial that they have pursued their claim on the wrong route, ${ }^{203}$ would be avoided altogether. Therefore, the article asserts that narrowing the scope of s.994 by removing the power to authorise derivative claims could feasibly result in the avoidance of lengthier and costlier proceedings. ${ }^{204}$

Despite these considerations, the article submits that, for the practical purpose of avoiding a multiplicity of proceedings, it is essential to retain the court's power under

\footnotetext{
${ }^{200}$ Gray (n 7) 299.

${ }^{201}$ Yap (n 25) 152.

${ }^{202}$ Law Commission: Consultation Paper (n 85) [9.1]- [9.53].

203 [2009] 5 HKLRD 743.

${ }^{204}$ Arad Reisberg, Derivative Actions and Corporate Governance (2007) 8.3.3.
} 


\section{Reconceptualising Shareholder Remedies to Mitigate the Problems Caused by the Overlap Between Section 994 and Part 11 Companies Act 2006}

s.996(2)(c). Retaining the power to authorise derivative claims would allow the courts to flexibly deal with circumstances where, for example, a derivative action is required to recompense the unfairly prejudicial treatment of the shareholder adequately. ${ }^{205}$ Furthermore, the article contends that where a shareholder successfully proves the unfair prejudice and seeks a personal remedy such as a purchase order in addition to a derivative action order, it may be wasteful for a separate derivative application to be made under Pt 11 based on essentially the same facts. ${ }^{206}$ Where the second solution viz., the removal of the derivative claim jurisdiction under Pt 11 CA 2006 is concerned, the critical question is 'whether the s.994 remedy provides for what the derivative claim seeks to in a more effective or theoretically sound manner? ${ }^{207}$ As Robin Hollington QC states, a Wallersteiner indemnity for costs is a factor that allows derivative claims to supersede the petition in this context. ${ }^{208}$ However, with Cutland fastening the possibility of being awarded a 'Wallersteiner indemnity for costs' under s.994, the cost factor appears to be an inadequate argument to assert that the derivative jurisdiction supersedes the s.994 jurisdiction in this context. ${ }^{209}$ Nonetheless, the article submits that abolishing the statutory derivative action under Pt 11 CA 2006 would be an imprudent step because it completely discards the supposed 'usefulness of the given laws'. ${ }^{210}$ This article summarises the 'usefulness' of a derivative action in four ways.

Firstly, as Reisberg suggests, the derivative claim is an affirmative 'social force', operating as a 'powerful restraint' to those directors lured to act unlawfully. ${ }^{211}$ The same cannot be asserted regarding the unfair prejudice petition as the 'scope of judicial oversight' integral to the derivative claim is not found in a petition, meaning that under Pt 11 CA 2006 frivolous claims are dispensed at an early stage. ${ }^{212}$ Secondly, this article submits that derivative claims under Pt 11 CA 2006 act as a mechanism for warranting that justice is served to the company 'holistically', as opposed to simply upholding the petitioner's interests. ${ }^{213}$ Thirdly, as Sykes argues, derivative claims under Pt 11 CA 2006 effectively empowers the shareholders as, under the newly codified

\footnotetext{
${ }^{205}$ Yap (n 25) 152.

206 ibid.

${ }^{207}$ Gray (n 7) 301.

${ }^{208}$ Loughrey (n 189)

${ }^{209}$ Gray (n 7) 299; Clark (n 131) [405].

${ }^{210}$ Gray (n 7) 301.

211 ibid; Arad Reisberg, 'Judicial Control of Derivative Actions' (2005) Int'l Company \& Com.L.Rev. $335,339$.

${ }^{212}$ Reisberg, Derivative Actions and Corporate Governance (n 204) 339.

${ }^{213}$ Gray (n 7) 301.
} 
rules, shareholders can now bring a claim for mere negligence. ${ }^{214}$ Fourthly, Pt $11 \mathrm{CA}$ 2006 derivative regime allows the courts to reiterate the importance of the rule in Foss. $^{215}$ Therefore, in the hypothetical circumstance where the derivative claim jurisdiction is removed, the courts in cases such as Shun Tak Holdings, ${ }^{216}$ would be compelled to produce an outcome disregarding the positive functionalities of assessing the claim involving breach of directors' duties under the Pt 11 CA 2006 jurisdiction. Thus, it is essential to safeguard both regimes that enable a shareholder to commence a derivative claim. However, it is also important to mitigate the policy concerns arising out of different threshold tests and safeguard the majority rule in Foss. Thus, in subsection 3 the article provides a middle-ground solution to the debate at hand.

\section{Conclusions}

The reform proposal requires the court to operate the s.994 regime in accordance with the laws governing the commencement and continuation of derivative claims under $\mathrm{Pt}$ 11 CA 2006. In implementing this proposal, step one involves, upon founding the elements of s.994, assessing if the director's unlawful conduct involves 'negligence, default, breach of duty or breach of trust by a director of the company'. ${ }^{217}$ Step two requires the courts to deliberate over the position of the shareholders collectively prior to authorising a derivative claim under s.994. ${ }^{218}$ Therefore, the second stage proclaims the court must evaluate factors such as 'authorisation or ratification', ${ }^{219}$ the 'importance that a member acting in conformity with s.172 (duty to promote the success of the company) would attach to the claim',20 and the 'views of the disinterested shareholders'. ${ }^{221}$ In effect, the court is required to consider ss.263(2), 263(3) and (4) CA 2006 to determine whether the continuance of the claim is 'in the best interest of the company'. Safeguarding the company's interest is particularly crucial as consequently, it protects the interests of creditors who have an imperative stake in the success of the company. ${ }^{222}$ To facilitate the consideration of these factors by the court, the article recommends that legislative amendments be made to enable the court to give

\footnotetext{
${ }^{214}$ Paul Sykes, 'The continuing paradox: a critique of minority shareholder and derivative claims under the Companies Act 2006’ (2010) 29(2) C.J.Q. 205, 233.

215 Gray (n 7) 301.

216 [2009] 5 HKLRD 743.

${ }^{217}$ CA 2006, s 260(3).

218 Payne, 'Shareholders' Remedies Reassessed' (n 5).

${ }^{219}$ CA 2006, s 263(3)(c)(ii).

${ }^{220}$ CA 2006, s 263(3)(b).

${ }^{221}$ CA 2006 s.263(4).

222 Yap (n 25) 153.
} 


\section{Reconceptualising Shareholder Remedies to Mitigate the Problems Caused by the Overlap Between Section 994 and Part 11 Companies Act 2006}

instructions as to the evidence that must be supplied by the petitioner, in a manner similar to s.261(3)(a).223

Under the proposed solution, the shareholder who seeks the remedy of a derivative action under a petition must establish an unfair prejudice as well as satisfy the substantive elements imported from Pt 11 as mentioned above. Thus, the solution makes it more onerous to obtain permission for a derivative action under the petition than under Pt 11 CA 2006. The Law Commission, examining cases reported in 'Butterworth's Company Law Cases' found that proceedings under s.994 are generally costly and lengthy in the measure of weeks rather than days. ${ }^{224}$ Therefore, when implementing the proposed solution, the cost and time factor may appear to be more inconvenient as the petitioner will have to establish both unfair prejudice and the $\mathrm{Pt} 11$ CA 2006 elements. However, the reform proposal, albeit being a roundabout way of obtaining justice, in effect reaches a middle-ground solution. On the one hand, it enables the court to flexibly deal with circumstances where a derivative action is necessary to redress the unfairly prejudiced shareholder. On the other hand, it solves the policy problems arising out of the different threshold tests as both the regimes will operate according to Pt 11 CA 2006 requirements and reinstates the rule in Foss as the court will examine issues of ratification and authorisation by the company. Streamlining the threshold tests allows the court to employ s.994 in a manner which protects the company from frivolous and unmeritorious claims. ${ }^{225}$ In conclusion, implementing the solution will, in sum, provide greater certainty, predictability and improved coherence within the framework of CA 2006.

\footnotetext{
${ }^{223}$ CA 2006 s.261(3)(a).

${ }^{224}$ Law Commission, Shareholder Remedies (Law Com No 246, 1997) para 1.6.

225 Tony Singla, 'Case Comment: Unfair Prejudice in the Privy Council' (2007) 123 L.Q.R. 542, 542-46.
} 
